\title{
Hippias Major 301b2-c2: \\ Plato's Critique of a Corporeal \\ Conception of Forms and of the \\ Form-Participant Relation
}

\section{David Wolfsdorf}

\section{I i Introduction}

In the final movement of the investigation in Hippias Major, Socrates and Hippias agree that unlike pleasures experienced through taste, touch, and smell, pleasure experienced through sight (Ps), pleasure through hearing $(P h)$, and pleasure through both sight and hearing ( $P$ sh) are

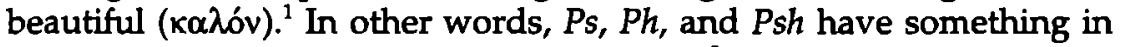
common, call it $K$, that makes them beautiful. ${ }^{2}$

I will speak of $K$ as a continuous property, where by a continuous property I mean that if two entities (be they particulars or properties) separately possess a property, then the two entities conjointly possess that property, and vice versa. Accordingly, $P s$ and $P h$ each possess $K$; and $P$ sh, which is a conjunction of $P s$ and $P h$, possesses $K$. Socrates notes: 'If these pleasures [ $P s$ and $P h]$ are conjointly affected by something, but

1 Throughout I maintain the traditional translation of ' $x a$ hóv'. I agree with Woodruff (1981) that 'fine' has a broader semantic range and in this respect is a more adequate translation; but 'fine' also seems to me rather anemic. In fact, no single English word is satisfactory.

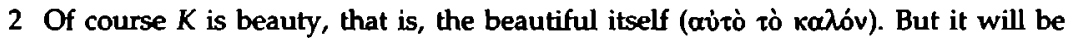
convenient to be able to refer to beauty by both means. 
separately not so affected, then they would not be beautiful because of that affection' (Hp Ma 300b4-5).

In confirming this condition of $K$, Socrates' statement also suggests the possibility of a contrary kind of property, call it a discontinuous property. By a discontinuous property I mean that if two entities separately possess a property, then the two entities conjointly do not possess that property, or vice versa. ${ }^{3}$ In the dialogue Socrates uses the example of duality; two individuals are conjointly, but not separately, a duality.

Since Hippias maintains that $K$ is a continuous property, ${ }^{4}$ he agrees to Socrates' statement. But, regardless of $K$, Hippias also rejects the possibility of discontinuous properties that Socrates' statement implies:

Socrates, your reply seems to contain wonders even greater than your previous reply. For consider this; is it not the case that if both of us were just, then each of us would be? Or if each of us were unjust, then both of us would be? Or if both of us were healthy, then each of us would be? Or if each of us were tired or wounded or struck or affected in any way whatsoever, then both of us would be so affected? Furthermore, if both of us were golden or silver or ivory, or, if you will, of noble birth, wise, honored, old, young, or anything else you wish that happens to humans, is it not greatly necessary that each of us would be? ( $\mathrm{Hp} \mathrm{Ma}$ 300e7-301a7)

In view of this range of properties, Hippias insists that there are no discontinuous properties. Moreover, Socrates' belief that there may be discontinuous properties elicits the following general criticism of Socrates' discursive practice:

But you see, Socrates, you do not consider the wholes of things ( $\tau$ ò ö $\lambda \alpha$ $\tau \hat{\omega} v \pi \rho \alpha \gamma \mu \alpha \dot{\alpha} \tau \omega)$, nor do those with whom you are accustomed to hold

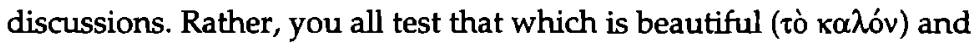

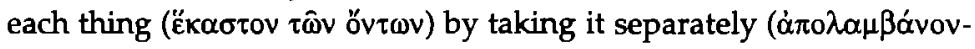

3 Note that neither Socrates nor Hippias speaks of the Greek equivalent of continuous or discontinuous properties; I employ these phrases to facilitate the exegesis. On the other hand, the word 'continuous' is based on the Greek 'סıaventis', which Hippias and Socrates use.

4 On whether Plato or his characters actually recognize property as an ontological kind, see Section III iv. 


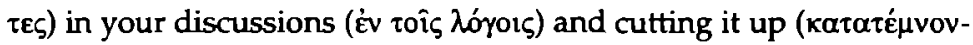
$\tau \varepsilon \varsigma$ ). And for this reason it escapes you that bodies of essence ( $\sigma \dot{\omega} \mu \alpha \tau \alpha$

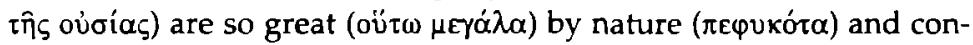

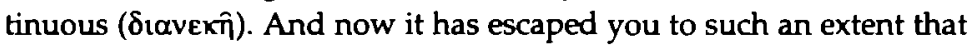
you think there is something ( $\tau 1)$, either an affection ( $\pi \alpha^{\prime} \theta 0_{\zeta}$ ) or an essence (ovioi $\alpha v$ ), which exists in the case of these things [Ps and $P h$ ] conjointly, but not separately, or in the case of each, but not both. You

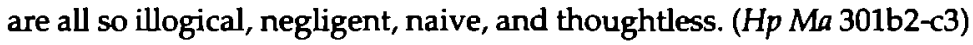

The objective of this paper is to explicate this passage, Hippias' criticism of Socrates.

\section{I ii Status quaestionis}

Over the last century, three sustained examinations of Hippias Major 301b2-c2 have been published. The first occurs in Eugène Dupréel's La légende socratique et les sources de platon of $1922 .{ }^{5}$ Dupréel argues that Hippias attacks Socrates' commitment to 'réalisme idéaliste', that is, to the metaphysical realist position that Forms (des Idées) exist separately from concrete beings. In 1927 Auguste Diès severely criticized Dupréel's interpretation as an extravagant departure from the text - 'comment osez-vous en tirer tout un système de métaphysique?'6 - and replaced it with a reading wholly innocent of metaphysics.

The third discussion is Michael Morgan's 'The Continuity Theory of Reality in Plato's Hippias Major' of 1983.7 Morgan, like Dupréel, regards Socrates and Hippias' exchange as metaphysically significant: 'There is here metaphysics of an incipient and undeveloped sort but explicit metaphysics nonetheless ${ }^{\prime}{ }^{8}$ But note that between the francophone literature on Plato of the twenties and the American literature of the eighties, the concept of metaphysics has undergone a shift. Morgan does not mean to imply that Hippias Major refers to or intimates transcendent Forms.

5 (1922), 190-213

6 (1927), 182-209; the quotation is from 194.

7 (1983)

8 lbid., 152 
Rather, metaphysical discourse is distinguished by its preoccupation with concepts pertaining to fundamental aspects of being, whatever these may be.

Morgan appears to be ignorant of Dupréel's and Diès' contributions, for he mentions neither. Morgan also neglects Paul Woodruff's edition of Hippias Major of 1981. Woodruff has but brief comments on 301b2-c2. Still, it is worth noting that he rejects Dupréel's treatment as 'madcap' and cites Diès' discussion approvingly. ${ }^{9}$

In short, Morgan's discussion occurs in a relative vacuum, and Dupréel's and Dies' papers are now eighty years old. If Woodruff were correct in support of Diès, there would be little to add to a discussion of the Hippias Major passage. Though I too believe that Dupréel's conclusions are inadequately grounded in the textual evidence, I am dissatisfied with Diès' metaphysically sterilizing response and Woodruff's endorsement of it. ${ }^{10,11}$ I agree with Morgan that Hippias and Socrates' exchange is metaphysically pregnant, understanding metaphysics in the recent sense. But I disagree with Morgan in a number of respects.

I will argue for the following theses:

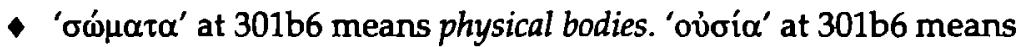

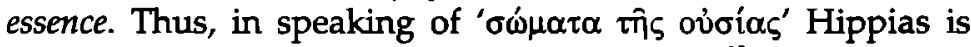
conceptualizing essences as spatially extended. ${ }^{12}$

- Hippias uses ' $\pi \rho \hat{\alpha} \gamma \mu \alpha$ ' at 301b3, like 'ôv' at 301b5, as an all-purpose word for any kind of thing. (I will translate both words as 'entity' or 'thing'.) An important consequent of this is that ovoíal

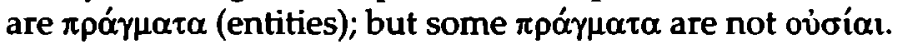

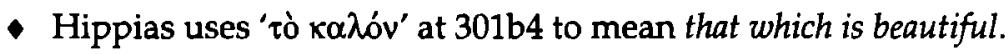

9 (1981), 85-6

10 By 'metaphysically sterilizing' I mean dismissal of metaphysics in both senses.

11 Note that the passage has certainly received comments by other scholars, for example, Apelt (1907), n 2; Tarrant (1928), 76-9; Soreth (1953), 55-7. However, their remarks are cursory. Note that Ludlam (1991) does not discuss the passage.

12 By 'conceptualizing essences as spatially extended' is meant that essences are conceived as physical bodies, that is, as three-dimensional. 
As such, 'tò $\kappa \alpha \lambda$ óv' $^{\prime}$ ranges over entities that have the property beauty; it does not refer to the property beauty itself. ${ }^{13}$

- In claiming that Socrates tends to cut up tò $\kappa \alpha \lambda$ òv and each thing

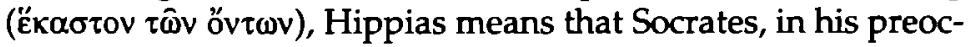
cupation with the 'What-is-F?' question, abstracts the essence (beauty) from things that have the essence (things that are beautiful). This tendency to abstract $F$ from entities that have $F$ results in Socrates' false belief in the existence of discontinuous properties.

- Hippias does not explain precisely how Socrates' tendency to abstraction misleads Socrates to assume the existence of discontinuous properties. However, Hippias does emphasize two points about essences, one regarding their spatial extension, the other regarding their continuity. In speaking of bodies of essence as 'oü $\tau \omega \mu \varepsilon \gamma \alpha \dot{\alpha} \lambda \alpha$ (so great)' at 301b5-6, Hippias means that the spatial extension of essences is equal to the entities that possess them. In speaking of bodies of essence as 'otovekn (continuous)' at 301b6, Hippias means that all entities of a given kind possess the corresponding essence. The spatial extension and continuity of essences contradicts the hypothesis of discontinuous properties.

- ' $\pi \alpha \theta_{0}$ os' at $301 \mathrm{~b} 8$ means affection (not property or accident). The contrary of $\pi \alpha \dot{\theta} \theta 0 \varsigma$ is $\pi$ orí $\mu \alpha$ (action). At $301 \mathrm{~b} 8$ Hippias applies his claims about the spatial extension and continuity of ovjoíal to $\pi$ á $\theta \eta$. Here too Hippias indicates that he is non-committal about whether beauty is an essence or an affection.

- Socrates' mathematical examples, for instance, unity and duality, ${ }^{14}$ suggest that the continuity principle does not apply to all properties. In other words, some discontinuous properties exist. Moreover, the existence of discontinuous properties suggests that at least some essences should not be conceived as spatially

13 Given the self-predicability of beauty, it is more accurate to say that $\tau$ ò $\alpha \alpha$ óv ranges over entities that are beautiful, except beauty itself.

14 See Hp Ma 301d5-2b3; and for other examples see 303b6-c2. 
extended. Indeed, this is the principal reason why Plato includes Hippias' criticism of Socrates and Socrates' rebuttal: to criticize a corporeal conception of Forms and of the Form-participant relation.

My account of Hippias and Socrates' exchange principally differs from Morgan's in the following five respects. First, Morgan explicates Hippias' 'continuity theory of reality' using a concept slightly different from that of a continuous property, call it an M-continuous. By an M-continuous property I mean that if two substances, that is, concrete particulars, separately possess a property, then the two substances conjointly possess that property, and vice versa. Accordingly, the difference between a continuous property and an M-continuous property is that the former can be a property of properties, whereas the latter can only be a property of concrete particulars. Clearly, Hippias does not merely want to commit to M-continuous properties, for Ps, Ph, and Psh themselves are properties, not concrete particulars.

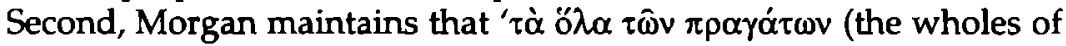
things)' at 301b2-3 refers to aggregates of concrete particulars of a kind, for example, the set of beautiful things. Third, Morgan maintains that

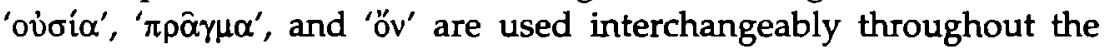
passage. Fourth, Morgan does not explain the disjunction of 'ov $\sigma i \alpha^{\prime}$ ' and ' $\pi \alpha \theta_{0 \varsigma}$ ' at 301b8, nor Socrates' subsequent uses of the terms. Fifth, Morgan does not explain the function of Socrates' and Hippias' exchange within the broader investigation.

Finally, it must be noted that my interpretation of Hippias Major $301 b 2-c 2$ proceeds upon the assumption that the dialogue was composed by Plato and belongs among the early dialogues. ${ }^{15}$

15 Woodruff (1981, 94-103) provides, to my mind, a satisfactory response to Thesleff's (1976) argument against the dialogue's authenticity. Moreover, as Woodruff notes, stylometric studies have consistently confirmed the authenticity of the dialogue. Other notable contributions to this debate include Grube (1926) and (1929) and Hom (1964). Kahn (1985) remains an important dissenting voice that has not been directly answered. On the other hand, Kahn's argument has not persuaded many scholars. Most treatments of Plato's early dialogues since 1985 include Hippias Major. Still, in view of the state of the controversy, my argument for authenticity is hypothetical. I assume the authenticity of the dialogue and develop my discussion on the basis of this assumption. The cogency of my conclusions supports the dialogue's authenticity. 
In his criticism of Socrates, Hippias speaks of 'bodies of essence ( $\sigma \omega \dot{\omega} \mu \tau \tau \alpha$

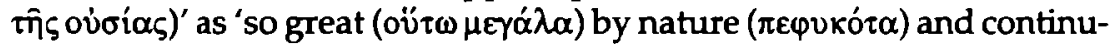
ous $(\delta เ \alpha v \varepsilon \kappa \pi)$ '. The word ' $\sigma \omega \mu \alpha \tau \alpha^{\prime}$ suggests physicality. Accordingly, Dupréel claims that 'Hippias met à la base de sa philosophie l'affirmation des êtres individuels', and he describes these as 'êtres concrets' ${ }^{16}$

The view that Hippias commits to some kind of materialism was already familiar in the first decade of the twentieth century, for in 1907 Otto Apelt criticized it." Apelt proposed to emend ' $\sigma \dot{\omega} \mu \alpha \tau \alpha$ ' to ' $\sigma \chi \eta^{17}$ $\mu \alpha \tau \alpha^{\prime}$. His reason relates to Socrates' response to Hippias' criticism. Socrates responds by citing unity and duality as discontinuous properties and by suggesting that if Hippias' continuous account of essence

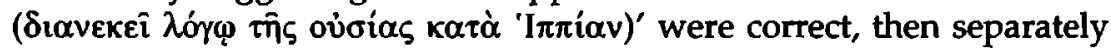
Socrates and Hippias would be two because conjointly they are two.

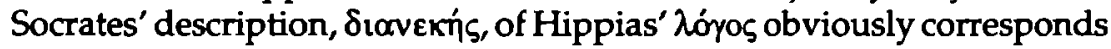
to Hippias' description of $\sigma \omega \omega_{\mu \alpha} \tau \alpha$ as $\delta$ เ $\alpha v \varepsilon \kappa \hat{\eta}$. Apelt claims that in this particular context ' $\lambda$ ó $\gamma o \varsigma^{\prime}$ ' means Verhältnis and that accordingly in Hip-

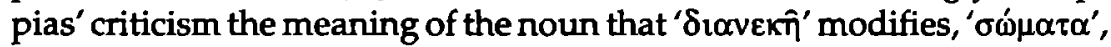
must semantically correspond. ${ }^{18}$ Consequently, Apelt concludes that ' $\sigma \omega \dot{\omega} \mu \alpha \tau \alpha$ ' must be a scribe's confusion of ' $\alpha \chi \eta \dot{\eta} \mu \tau \alpha$ ', which he translates as 'Verhältnisse'. ${ }^{19}$

Grube characterizes Apelt's emendation as 'drastic' ${ }^{20}$ Indeed, Apelt's argument is feckless. There is no reason to attribute an unusual sense to the word 'tóyos' here; one of its standard meanings, account, will do. Socrates' description of Hippias' account as continuous refers to the

16 (1922), 200-1

17 'Kein Wunder, daß das närrische ó́uata nicht etwa bloß Antoß erregt, sondern zu den verwegensten Vermutungen über angebliche Beziehungen zu gewissen materialistischen Philosophemen Anstoß gegeben hat' (n 2). Apelt mentions by name only one proponent of such 'Vermutungen', Dümmler (1889).

18 '... der hiesigen Bedeutung von $\lambda$ óyos (Verhältnis) entspricht' (n 2). Note that the manuscript tradition is consistent on the reading ' $\sigma$ ' $\mu \alpha \tau \alpha^{\prime}$; see Vancamp (1996), 102.

19 'Dies Wort dürfte kein anderes sein als $\sigma x \dot{\mu} \mu \alpha \alpha^{\prime \prime}$ "Verhältnisse", das vortrefflich paßt und als seltener vorkommend mit dem häufigen $\sigma \omega ́ \mu \alpha \tau \alpha$ graphisch leicht verwechselt werden konnte' (n 2).

20 (1926), 148 
content of the account, not to the account as an entity itself. Compare the phrase 'materialist theory'.

A second attempt to skirt the physicalist significance of ' $\sigma \dot{\omega} \mu \alpha \tau \alpha$ ' is to attribute to it a figurative sense. Woodruff, who translates 'bodies', claims that "body" does not appear to have the significance it has in Sophist $247 \mathrm{bc}$ [where it is described as that which can be handled and is resistant to touch] ${ }^{21}$ However, Woodruff provides no further comment on the sense it does have. Dorothy Tarrant is more explicit. She notes that Plato normally uses $\sigma \hat{\omega} \mu \alpha$ in the obvious physical sense, as a correlative to $\psi v \chi \chi^{\prime}$ ', and she suggests that ' $\sigma \omega \mu \alpha \tau \alpha$ may ... be here used in the figurative sense ("masses") as a piece of philosophic slang'.

It is necessary to distinguish two figurative senses of ' $\sigma \hat{\omega} \mu \alpha$ ' from the primary sense. The primary sense of ' $\sigma \hat{\omega} \mu \alpha$ ' in the fourth century BC is the body of a human or animal. Accordingly, as Tarrant observes, among Plato's dialogues, $\sigma \hat{\omega} \mu \alpha$ and soul often are correlatives. The first figurative sense is the one Tarrant mentions: ' $\sigma \hat{\omega} \mu \alpha$ ' refers to any physical object. For example, in Phaedrus Socrates says: 'Every body $(\sigma \hat{\omega} \mu \alpha)$ whose source of motion is external to it is soul-less'. ${ }^{23}$ The second figurative sense is an aggregate or whole. For example, when in Timaeus Timaeus

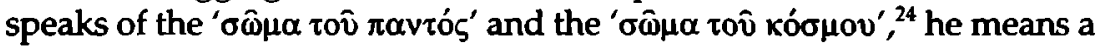
physical whole of physical constituents. But in this second figurative sense, the body qua aggregate or whole need not be composed of physical objects. For example, when Aristotle in Rhetoric speaks of the ' $\sigma \hat{\omega} \mu \alpha$ in̄ $\pi i \sigma \tau \varepsilon \omega \varsigma^{\prime}$, that is, the set of reasons that constitute an argument, ${ }^{25}$ he is referring to what may be called a logical kind.

At Hippias Major 301b6 ' $\sigma \omega \dot{\omega} \mu \alpha \alpha^{\prime}$ ' obviously cannot have its primary sense. The first figurative sense is, at least, consistent with Dupréel's view that Hippias here has in mind concrete particulars. Accordingly, in criticizing Dupréel, Diès argues for the second figurative sense: 'Tout le monde est habitué à cet emploi du mot corps dans le sens de dimension,

21 (1981), 85, n 175

22 (1928), 79

23 Phdr 245e

24 Ti 31b, 32c

$25 R h$ 1354a15 
épaisseur, volume, masse, substance, et l'on parle chez nous d'un corps de logis, comme d'un corps de voilure, mais aussi ... du corps de la langue ${ }^{26}$

Diès' contrast between corps de logis and corps de voilure, on the one hand, and corps de la langue, on the other, suggests that he means to convey that 'corps' is ontologically neutral. He proceeds to cite from Montaigne a passage in which that author speaks of 'les corps des livres'. ${ }^{27}$ Given that a body of books consists simply of the books, Diès

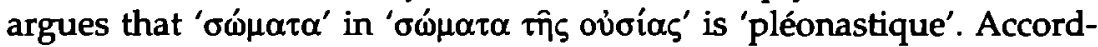
ingly, ' $\sigma \omega \alpha \alpha \tau$ ' has no ontological significance. In other words, the

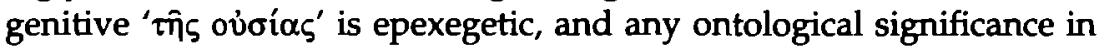

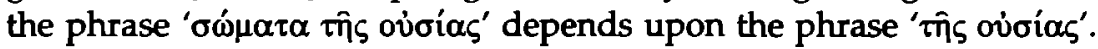
Diès commends Croiset's translation, 'les grandes reálités continues des essences', as 'peut-être un peu rapide, mais ... exacte au fond' ${ }^{28}$ The reason for the qualification, 'peut-être un peu rapide', is that Diès thinks Croiset has gone too far in translating 'ovं ${ }^{\prime} \alpha$ ' as 'essence'. ${ }^{29}$

We will come to 'ovं ${ }^{\prime} \alpha^{\prime}$ ' shortly. Presently, let us emphasize the fallacy in Diès' argument. The way the French use the word 'corps' is of course irrelevant to the question of the meaning of the Greek ' $\sigma \tilde{\omega} \mu \alpha^{\prime}$ ' in Hippias Major. That is to say, Diès offers no evidence from Plato to support his figurative interpretation of ' $\sigma \hat{\omega} \mu \alpha$ ', namely, the second figurative sense. Precisely, Diès owes his readers at least one instance of ' $\sigma \hat{\omega} \mu \alpha^{\prime}$ ' in Plato applied to a whole that is not physical. We have found an instance in Aristotle, but I know of none from Plato. Therefore, the evidence strongly supports interpreting ' $\sigma \dot{\omega} \mu \alpha \tau \alpha^{\prime}$ ' according to the first figurative sense. In other words, ' $\sigma \omega ́ \mu \alpha \tau \alpha^{\prime}$ is not ontologically neutral; Hippias is here speaking of physical bodies. ${ }^{30}$

26 (1927), 195

27 'Car les Lancelots du Luc, des Amadis, des Huons de Bordeaus, et tel fatras de livres à quoy l'enfance s'amuse, je n'en connoissois pas seulement le nom, ny ne fais encore le corps, tant exacte estoit ma discipline' (195).

28 Ibid., 196

29 'Qu'est-ce que cette ov̉oía que je traduis, avec M. Croiset, par essence?' (196)

30 It is also noteworthy that even if Diès were correct in his contention that ' $\sigma \hat{\omega} \mu \alpha$ ' is ontologically neutral, it still needn't be pleonastic. Consider that the phrases 'the books' and 'the body of books' may have the same referent, but not the same meanings; contrast 'Plato's corpus contains 36 dialogues' with 'Plato's dialogues contain 36 dialogues'. 


\section{III $\mathbf{i}$ ovjoía in Plato's Early Dialogues}

But what are bodies of ovoi $\alpha^{\prime}$ ? Thesleff characterizes to the phrase as 'vexed'. ${ }^{31}$ Grube speaks of it as a 'rather queer expression'. He suggests that the meaning is 'not clear, but we should remember that Hippias is probably purposely represented as obscure. He is camouflaging his ignorance with big words that mean little'. ${ }^{32}$ Kahn claims that 'such confused and sometimes obscure terminology is not to be found in Plato, where the role of ov $\sigma i \alpha$ as nominalization either of veridical $\varepsilon \hat{i} v \alpha \iota$ or of the $\tau i$ ' $\sigma \tau \tau$ question is normally clear from context ${ }^{\prime}{ }^{33}$ Moreover, Kahn claims that the dialogue 'repeatedly uses ovoí as a frozen technical term, as in Aristotle or even later' ${ }^{34}$

On the assumption that Hippias Major was composed by Plato and is among his early dialogues, it will be helpful to examine the use of 'ov' $\sigma \alpha^{\alpha}$ ' in these texts. Outside of the instance of 'ovjoía' at Hippias Major $301 \mathrm{b6}$ and three others in its immediate vicinity (301b8, e4, 302c5), the word occurs eight times among the early dialogues. Four instances with the meaning property (as in real estate) are irrelevant. ${ }^{35}$ The remaining four are germane. At Meno 72b1, Socrates uses the analogy of bees to explain the meaning of his 'What-is- $F$ ?' question (hereafter referred to as the WF question):

If I were asking of a bee with regard to the ovoi $\alpha$, what it is, and you answered that there are many and various bees, what would you reply if I said: "Do you mean that they are many and varied from one another insofar as they are bees?" (Men 72b1-5)

\section{1 (1976), 113}

32 (1926), 147; Grube continues. 'We may perhaps see here a quotation (or a parody?) of a passage from one of the sophist's works. But I do not believe that Hippias is putting forward a deeply thought-out theory of nature, although he doubtless thinks it deep enough. Nor is some rival school of thinkers made to speak through him, for in either case he would express himself more clearly and probably more at length' (147).

33 (1985), 270; Kahn cites Euthphr 11a7 and Phd 65d13, 76d9 as examples of genuine Platonic uses of ovioía.

34 Ibid.

35 Grg 472b6, 486c1; Cri 44e5, 53b2 
Meno admits that bees are the same qua bees. Accordingly, the passage suggests that an ovoí $\alpha$ is what a thing is. In other words, as Kahn

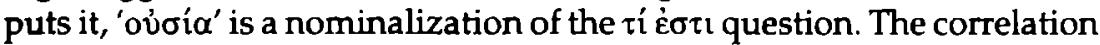
between oúoia and the WF question helps. For instance, in Euthyphro

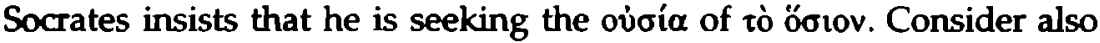
Socrates' response to Polus in Gorgias when Polus, in response to Socrates' question 'What is rhetoric?', characterizes rhetoric as the finest craft: No one was asking you what sort ( $\pi$ oi $\alpha$ ) of craft Gorgias' is, but what (ric) it is?' (Grg 448e6-7) Polus' unsatisfactory answer here is also similar to his unsatisfactory answer later in the dialogue when, following Socrates' account of rhetoric as a kind of flattery, he says: 'So you think that rhetoric is flattery?' Socrates responds: 'I said that it is a part of flattery' (Grg 466a4-6). Both here and earlier in the dialogue Polus confuses (what we call) identification with predication. Accordingly, to give the ovoia of a thing is to give its identity. Of course, the way Plato conceives of the identity of a thing is largely pretheoretical and remains vague.

At Protugoras 349b1-5 Socrates asks Protagoras:

Are knowledge, sound-mindedness, courage, justice, and holiness five

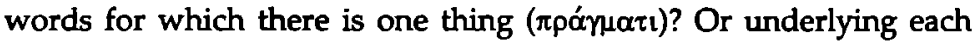
name is there a particular ovoi $\alpha$ where each thing ( $\pi \rho \hat{a} \eta \mu \alpha)$ has its own

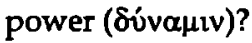

The referent of each excellence-term, whether or not the excellenceterms are coreferring, is a $\pi \rho \hat{a} \gamma \mu \alpha$. Here in Protagoras an ovjoí $\alpha$ is described as a $\pi \rho \hat{\alpha} \gamma \mu \alpha$; but ' $\pi \rho \hat{\alpha} \gamma \mu \alpha$ ' can be used as an all-purpose word for any kind of thing. This is clear from the following passage in Hippias Major: '[So:] We have been seeking that thing by which all beautiful

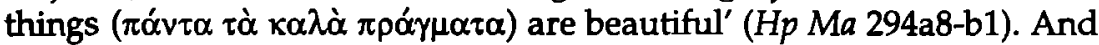
elsewhere in the dialogue Socrates describes a range of beautiful things as follows:

Don't you remember that I was asking about the beautiful itself, whose addition to anything ( $\pi \alpha v \tau i$ ) makes that thing beautiful, be it a stone, a stick, human, god, every action and course of study. (Hp Ma 292c9-d3)

We call the whole human body beautiful, sometimes for running, sometimes for wrestling. And the same is true for all animals. We call a horse beautiful, a rooster, a quail, and all equipment and vehicles, both those used on land and those used at sea, cargo ships and warships, as well as all tools, instruments used in music and in all the other 
crafts, and still further, if you will, pursuits and customs, we basically call all of these things beautiful in the same way. ( $\mathrm{Hp} \mathrm{Ma} \mathrm{295c8-d6)}$

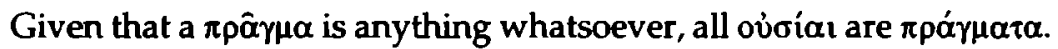

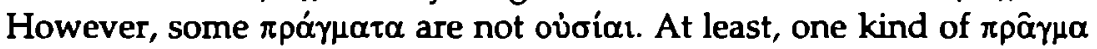
does not include ovjoía. The WF question seeks an account of a universal, not a concrete particular. Thus, for instance, Socrates is not an ovioí - although he may have an ovoía.

The Protagoras passage also suggests a distinction between a thing and its power: 'Or underlying each name is there a particular ovoí $\alpha$ where each thing $(\pi p \hat{\gamma} \gamma \mu \alpha)$ has its own power ( $\delta \dot{v} v \alpha \mu t v)$ '. This distinction recalls Socrates' initial presentation earlier in the dialogue of the question whether excellence has parts: 'Does each [part of excellence] have its own particular power ... Is each distinct from the others both in itself ( $\alpha$ vitò) and in its power?' (Prt 330a4-b1). I take it that the distinction here between a thing itself and its power is equivalent to the distinction (at $349 \mathrm{~b}$ ) between a $\pi \rho \hat{\alpha} \gamma \mu \alpha$ or ovं ${ }^{\prime} \alpha$ and its power. Thus, in Protagoras we

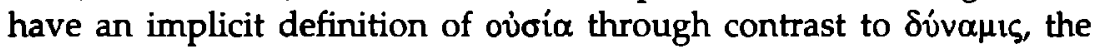
power of the thing.

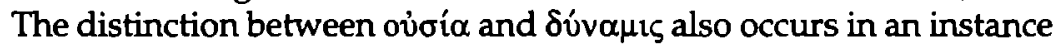
of 'ovंoía' at Charmides $168 \mathrm{~d} 2$. Socrates is considering the possibility of knowledge of knowledge. On the basis of a set of analogous examples, including vision of vision and hearing of hearing, he infers the following

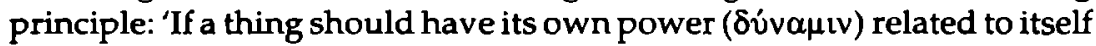

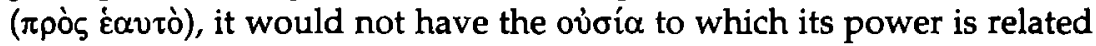

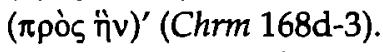

The example of vision of vision clarifies this principle. The power of vision is sight (where sight is understood as the entity that capacitates the act of seeing, not the act itself). The objects of sight are shape and color. Accordingly, the possibility of vision of vision, that is, of vision seeing itself, depends upon vision itself having shape and color. Because vision is colorless and shapeless, vision of vision is impossible, as the principle claims. The Charmides passage thus corroborates the distinction

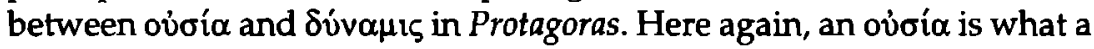
thing itself is, in contrast to what it is capable of doing.

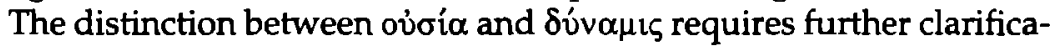

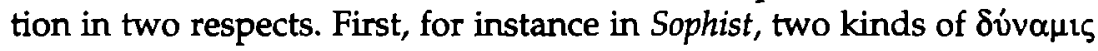
are distinguished: powers to act and powers to be acted upon or affected:

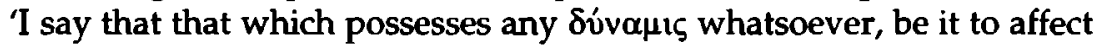
( $\pi$ oleiv) any other thing or to be affected ( $\pi \dot{\alpha} \theta \varepsilon \mathrm{e} v$ ), ... exists' (Sph 247d8e3). Among the early dialogues $\delta$ vó́ $\mu \in \iota \varsigma$ are consistently treated as 
powers to act. This may merely be a coincidence, or it may be Plato's deliberate simplification for pedagogical reasons. ${ }^{36}$ Second, 'ovं $\sigma i \alpha^{\prime}$ ' and

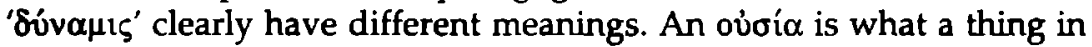

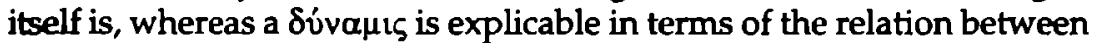

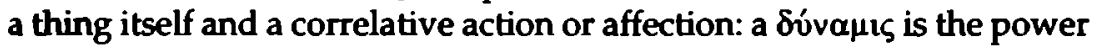
of a thing for a certain kind of action or affection. But the power of a thing, be it the power to act or to be affected, depends upon what the thing is. Compare the distinction between categorical and dispositional properties. In other words, power is based on an ovoía. In light of this, consider that in Laches Socrates clarifies his WF question by telling Laches that in seeking what courage is, he is seeking a dívouls.

One further instance of 'ovoía' among the early dialogues occurs at Euthyphro 11a8:

Euthyphro, it seems that when you were asked what the holy (iò öoiov) is, you were unwilling to make clear its ovoía; instead you described an affection ( $\pi \alpha^{\prime} \theta_{\circ \varsigma}$ ) of it, that is, something that this thing the holy ( But you have not yet said what it is. (Euthphr 11a6-b1)

As we have noted, ovoí $\alpha$ is here explicitly related to the WF question. Furthermore, Socrates implicitly defines ovioía in contrast to $\pi \alpha \theta^{\prime}$ os. In a recent discussion of this passage, I have emphasized that 'affection' or 'passion', rather than 'property', is the right translation of ' $\pi \dot{\alpha} \theta 0$ s' $^{\prime}$ and that the distinction between ovं $\sigma^{\prime} \alpha$ and $\pi \dot{\alpha} \theta 0 \zeta$ is not, as has sometimes been claimed, equivalent to the distinction between essence and accident. ${ }^{37}$ I show that the ovioi $\alpha-\pi \alpha$ ó 0 os distinction in Euthyphro includes two

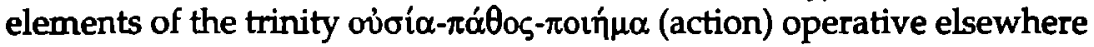
in the Platonic corpus. Пoเń $\mu \alpha$ and $\pi \alpha \dot{\alpha} \theta$ os are contraries, action and passion or affection. The relation of ovioía to $\pi$ orń $\mu \alpha$ and $\pi \dot{\alpha} \theta$ os should then be understood as follows. An ovjoi $\alpha$ is that which makes an entity the kind of thing it is. For example, a holy particular is so because it has the ovoi $\alpha$ holiness. Furthermore, ovं $\sigma^{\prime} \alpha$ are $\delta v v \alpha \dot{\alpha} \mu \varepsilon 1 \zeta$. Thus, the possession of an ovं $\sigma i \alpha$ enables an entity to act or to be affected in a specific way.

36 See Wolfsdorf (2006).

37 Wolfsdorf (2005) 
Two more points before returning to 'ovoía' at Hippias Major $301 \mathrm{b6}$. First, we have seen that in Meno Socrates speaks of the oviai a bees: 'If I were asking of a bee ( $\mu \varepsilon \lambda i \tau \tau)$ ) with regard to the ovoia, what it is ...'. And in Euthyphro Socrates speaks of the ovjoi $\alpha$ of to öotov: 'when you

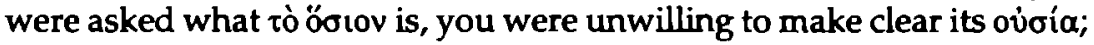
instead you described an affection ( $\pi \dot{\alpha} \theta 0 \varsigma$ ) of it, that is, something that this thing tò öotov has undergone ( $\pi \dot{e} \pi \circ \theta \theta \varepsilon$ ), being loved by all the gods'. In these instances, the relation between ovoía, on the one hand, and

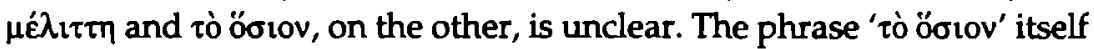
is ambiguous. It may be rendered holiness or that which is holy. In the former case, the relation between 'ov'oía' and the noun-phrase is epexegetic; compare 'the city of Rome'. In the latter case, the relation is possessive: the holiness possessed by that which is holy. In the case of the Meno passage ' $\mu \varepsilon \lambda_{1 \tau \tau \eta}$ ' is indefinite and singular; Socrates is asking about the ovoi $\alpha$ of any given bee. ${ }^{38}$ In other words, he is asking what makes any given bee a bee. In this case, the relation is possessive. In my

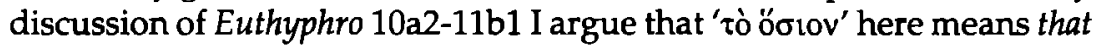
which is holy. Accordingly, again, the relation is possessive.

The second point concerns the relation between ovoia, on the one

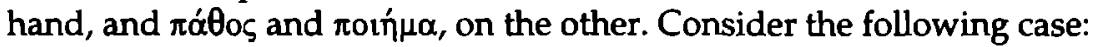
something that is holy is loved by the gods because it is holy; therefore, that holy thing has the $\pi \dot{\alpha} \theta 0 \varsigma$ of being god-beloved. ${ }^{39}$ Which of the following two accounts is more accurate: the holy thing is god-beloved, or the holiness of the holy thing is god-beloved? Consider a second case: Socrates sees the river, or Socrates' eye or sight sees the river? In Euthyphro, as I argue, Socrates speaks of something holy, rather than the holiness of something holy, being god-beloved - even though something holy is god-beloved because of its holiness. This suggests, as we would also naturally put it, that Socrates, rather than his eye or sight, sees the river. In that case, although we draw a distinction between a particular and the ovoi $\alpha$ that makes the particular the kind of thing it is, and although the ovoi $\alpha$ of the particular is responsible for its active and passive $\delta$ vóa $\mu \varepsilon \iota$, , we speak of the particular, not the ovioi $\alpha$, as acting and being affected.

Sharples $(1985,39)$ writes: 'if I asked you what constitutes being a bee'. 
So much for a survey of ovioí $\alpha$ among Plato's early dialogues. Return-

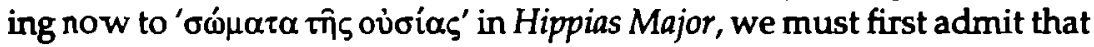
we cannot be sure that when he uses 'ov $\sigma \alpha^{\prime} \alpha^{\prime}$ at 301b6, Hippias is using it as Socrates would. However, if we assume that he is and cogent consequences follow, this supports the assumption. ${ }^{40}$

Consider again the first two sentences of Hippias' criticism:

But you see, Socrates, you do not consider the wholes of things ( $\tau \dot{\alpha}$ ö $\lambda \alpha$ $\tau \hat{\omega} v \pi \rho \alpha \gamma \mu \alpha \dot{\tau} \omega v)$, nor do those with whom you are accustomed to hold

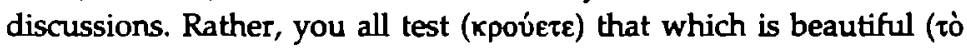

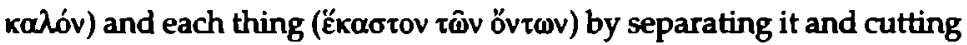
it up.

Hippias' contrast between the consideration of the wholes of things and Socrates' testing of that which is beautiful by separating and cutting it up indicates that ' $\pi \rho \alpha{ }^{\gamma} \mu \alpha \tau \alpha^{\prime}$ ' and 'ôv $\tau \alpha$ ' are coreferring and that $\tau \dot{0}$

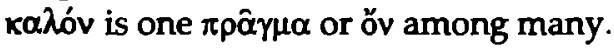

Note that Hippias refers to Socrates and his associates. I take it that Hippias includes Socrates' associates because Socrates has been referring to his tough-minded and aggressive housemate throughout the dialogue. Hippias assumes that the sorts of discussions Socrates and his associates hold are of the kind that Hippias himself and Socrates are holding now, that is, conversations in which that which is beautiful and each thing are tested. In other words, Hippias is thinking of investigations governed by the WF question.

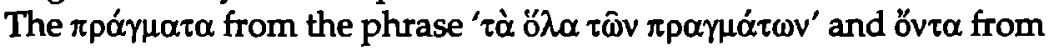

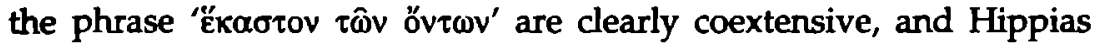
clearly understands 'iò $k \alpha \lambda^{\prime} v^{\prime}$ ' to designate one among the many

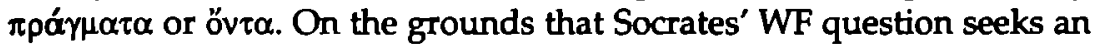
ovoí $\alpha$ it might be inferred that Hippias is here using ' $\pi \rho \alpha \dot{\gamma} \mu \alpha \tau \alpha$ ' and

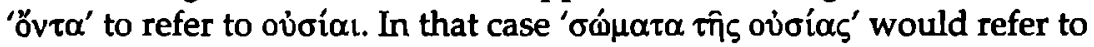
the physical bodies of definienda such as beauty. This is Morgan's view. ${ }^{41}$

40 This point is discussed further in section $\mathrm{V}$.

41 'Hippias's ... is a theory about things which can be called collectively ovoiat or

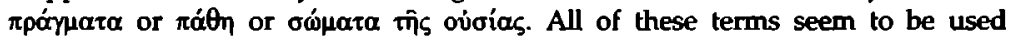
interchangeably ...' (1983) 140 . 


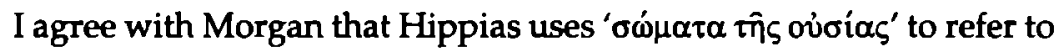
definienda such as beauty qua physical bodies. But, granted that Hippias

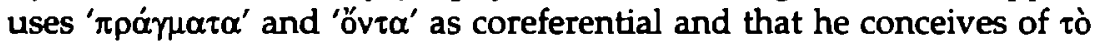
$x \alpha \lambda \log ^{2}$ as an öv or $\pi \rho \hat{\alpha} \gamma \mu \alpha, I$ disagree with Morgan that Hippias is using

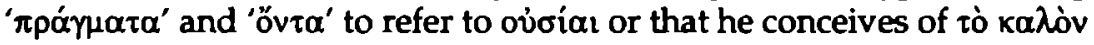
as an ovjoí $\alpha$. To understand why, it is necessary to return to the beginning of the investigation.

\section{III ii 'tò ka óo'}

When Socrates first poses the WF question, Hippias and he engage in the following exchange:

[So:] Tell me ... what is this thing tò kalóv? [Hi:] Socrates, does he who asks this question want to learn anything other than what is ka ${ }^{2}$ ov? [So:] I don't think so - rather, what is tò ka $\lambda$ óv, Hippias. [Hi:] But what is the difference between these questions? [So:] Don't you think there's a difference? [Hi:] No, they don't differ at all. [So:] Well, clearly your knowledge is more beautiful. But all the same, consider ... for he is not

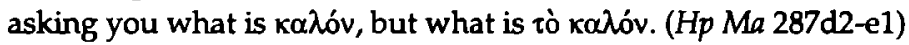

At the beginning of the investigation, Plato emphasizes Hippias' failure to distinguish the meanings of the questions 'What is to ka $\alpha$ óv?' and 'What is koגóv?'. We might think that Hippias' problem is metaphysical: he cannot distinguish the property from the entity that has the property; he cannot distinguish beauty from that which is beautiful. But the problem also has a linguistic dimension.

The phrase ' $\tau$ ì $\alpha \alpha \lambda$ óv' $^{\text {and }}$ phrases similarly composed of the neuter definite article and adjective, which I will call tò phrases, ${ }^{42}$ are semantically ambiguous. Plato often uses tò phrases as referring expressions, specifically to refer to Forms. But tò phrases are also used, in and out of

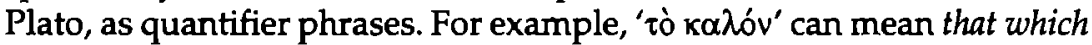
is beautiful. The use of to phrases as Form-designators in fact derives from the use of to phrases as quantifier-phrases. Assume that ' $\rho$ stands for the 
adjective corresponding to the general term ' $F$ '; for example, 'orotov' (holy) relative to 'oøióms' (holiness). In posing his WF question in the form 'What is to $f ?$ ', Socrates means 'What is that which is $f$ qua $f$ (or insofar as it is $f$ ?'. Here the phrases 'qua $f$ and 'insofar as it is $f$ are restricting qualifications. When the to phrase is used as a quantifier phrase, the article 'to' serves as the quantifier, and the adjective or adjectival phrase defines the domain over which the quantifier ranges. For example, in 'that which is holy', 'that which is' functions as a universal quantifier, and 'holy' defines the domain as the set of holy entities. The phrases 'qua holy' or 'insofar as it is holy' further restrict the domain over which the quantifier ranges, in this case to the property holiness that all holy things share; for that which is holy qua holy is the property holiness. Socrates sometimes explicitly attaches a restricting qualification to the $\tau$ ò phrase, namely the emphatic pronoun 'av่ ó' $^{\prime}$ (itself); for example, 'av่tò tò ka $\lambda^{\prime} v^{\prime}$. However, often he does not, but still intends the to phrase to refer to the Form $F$.

In sum, the phrase ' $\tau$ ò $\alpha \alpha \lambda o^{\prime}$ ' literally means that which is beautiful. But Socrates here understands it to mean that which is beautiful insofar as it is beautiful. Indeed, immediately prior to posing the WF question, Socrates asks a series of questions whose purpose is threefold: to distinguish $F$ from $f$ things, to affirm the existence of $F$, and to identify $F$ as responsible for things being $f$.

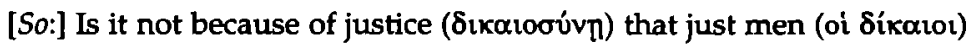
are just? [Hi:] I answer that it is because of justice. [So:] Then this thing

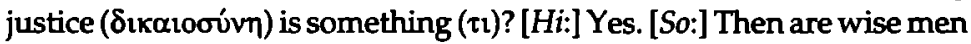

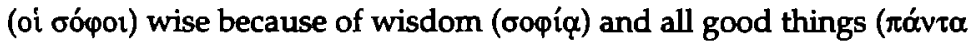
$\tau \dot{\alpha} \gamma \alpha \theta \dot{\alpha})$ good because of the good ( $\tau \hat{\varphi} \dot{\alpha} \gamma \alpha \theta \hat{\omega})$ ? [Hi:] How could it be otherwise? [So:] And these things [wisdom and the good] are something ( $\tau 1 \sigma)$...? [Hi:] Yes, they are something. [So:] Then is it not also the case that all beautiful things ( $\tau \dot{\alpha} \kappa \alpha \lambda \grave{\alpha} \pi \alpha ́ v \tau \alpha$ ) are beautiful because of the beautiful ( $\tau \hat{\varphi} \hat{\varphi} \kappa \alpha \lambda \hat{\varphi})$ ?' [Hi:] Yes, because of the beautiful. [So:] And

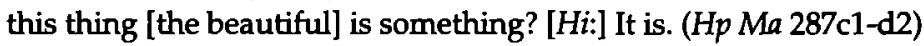

Embedded in this exchange are four propositions with a similar syntactic structure: just men are just because of justice; wise men are wise because of wisdom; all good things are good because of the good; and all beautiful things are beautiful because of the beautiful. In the first two

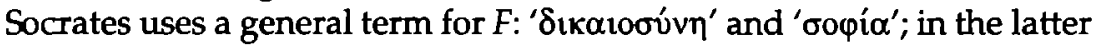
two he uses tò phrases. In the case of justice Socrates could have used the tò phrase 'tò díkalov'; conversely, in the case of the beautiful he could 
have used the general term ' $\alpha \alpha \lambda \lambda{ }^{\prime} \varsigma^{\prime} .{ }^{43}$ In using the mixture of general terms and to phrases Socrates intends to convey that although the forms differ grammatically, their semantic function is the same: they refer to $F$ rather than things that have $F$.

While Hippias assents to Socrates' questions, evidently he fails to appreciate their implications. ${ }^{44} \mathrm{His}$ misunderstanding manifests itself precisely in his failure to appreciate the distinction between the ques-

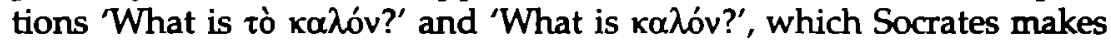
when, immediately following Hippias' assent to the preceding set of questions, he poses the WF question. Specifically, I suggest that Hippias interprets the to phrase in the WF question as a quantifier phrase such that he understands Socrates to be asking him: 'What is that which is beautiful?'. John Palmer agrees: 'When Socrates asks him what is the

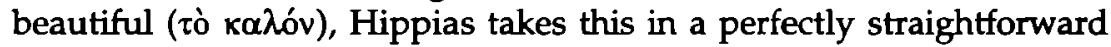
manner to mean: "what is that which is beautiful?" Thus he naturally

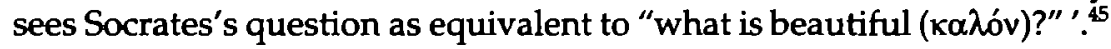

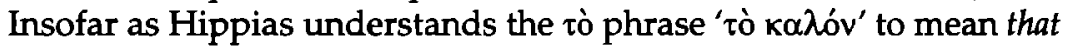
which is beautiful, he understands the phrase to distinguish entities that have $F$ rather than $F$ itself. So, for example, his first response to the WF question is a beautiful maiden.

At least at the beginning of the investigation, then, Hippias understands the phrase 'tò $\alpha \alpha \lambda$ v' $^{\prime}$ to mean that which is beautiful rather than beauty.

It might be argued, however, that in the course of the investigation Hippias comes to appreciate the semantic distinction between the ques-

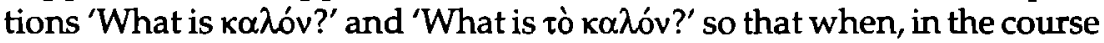

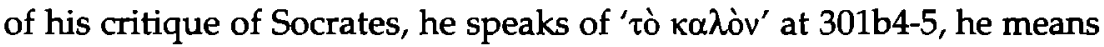
beauty. In fact, there is good reason to think that from the beginning to the end of the investigation, Hippias confuses the meanings of ' tò $\kappa \alpha \lambda$ óv' $^{\prime}$ and other $\tau$ ò phrases. Indeed, there is good reason to believe that Plato

43 Note that Socrates could not have used the general term ' $\dot{\alpha} \gamma \alpha \theta \omega \sigma v i v \eta^{\prime}$, which does not occur in the fourth century. Also, among the early dialogues Plato does not

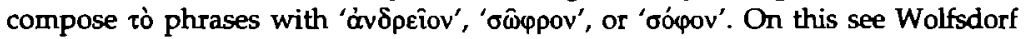
(2002), 203-5.

44 For a further explanation of Hippias' confusion, see Wolfsdorf (2003), 175-88.

45 Palmer (1999), 62 
actually deliberately plays upon the semantic ambiguity of the tò phrase late in the investigation.

The investigation in Hippias Major is divisible into three movements: Hippias' three definitions: a beautiful maiden, gold, and a paradigmatic Greek male life; Socrates' subsequent three definitions: the proper or decorous, the useful, and the beneficial; and Socrates' fourth and final definition: pleasure through sight and hearing, subsequently reinterpreted as beneficial pleasure. ${ }^{46}$ In criticizing his own third definition, Socrates develops the following argument:

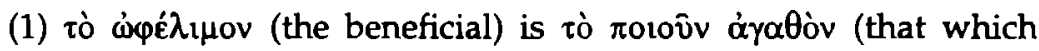
makes good).

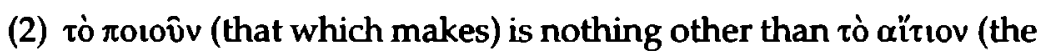
cause).

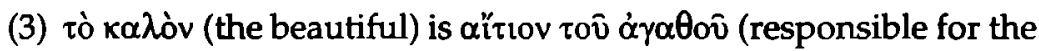
good).

(4) But the cause and that of which the cause is the cause are different.

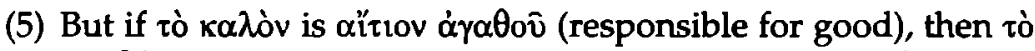

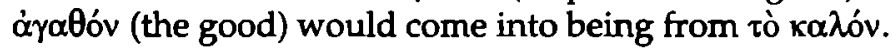

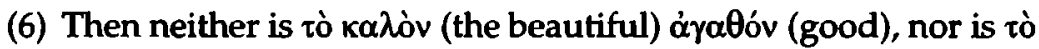

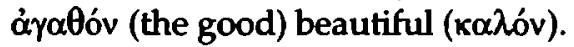

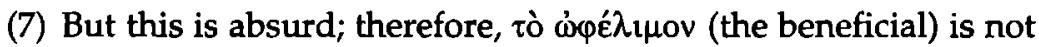

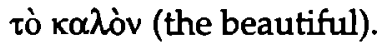

The argument contains a flaw that relates to the ambiguity of the io

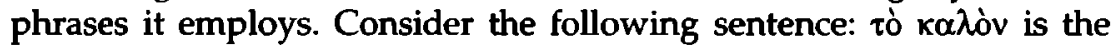

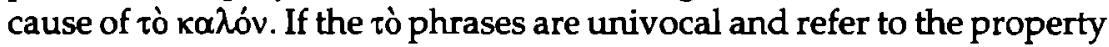
beauty, then the sentence is absurd insofar as it claims that something is the cause of itself. But if the tò phrases are bivocal, the first used as a referring expression, the second as a quantifier phrase, then the meaning

46 The reason for dividing Socrates' contributions into two movements will be explained in section IV. 
of the sentence is equivalent to the claim that beautiful things are beautiful because of beauty; in other words, beauty is the cause of that which is beautiful. Furthermore, given the self-predicability of beauty which Socrates assumes in the dialogue - beauty, qua cause of beautiful things, is itself beautiful.

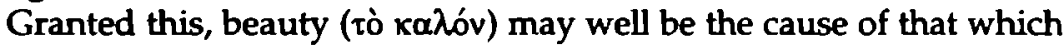

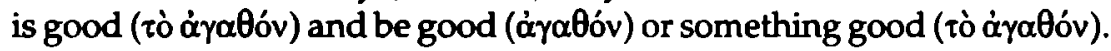
Precisely, if beauty and goodness are identical, then good things are good because of beauty, and, given the self-predicability of beauty, beauty is good.

The argument is faulty precisely because it fails to distinguish beauty and goodness, on the one hand, from beautiful and good things, on the other. So, for example, premise (3) is reasonable if the grammatical object

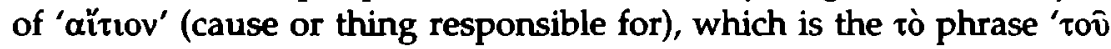
$\dot{\alpha} \gamma \alpha \theta 0 \hat{v}$ ' (the good), is interpreted not as a referring expression designating the Form or property goodness, but as a quantifier phrase ranging over good entities: viz., beauty is responsible for that which is good. However, ' $\tau 0 \hat{v} \alpha \gamma \alpha \theta 0 \hat{\text { ' }}$ ' in (3) is mistakenly interpreted as a referring expression. In short, the problems of Socrates' refutation of his third definition directly relate to the semantic ambiguities of the to phrase that were adumbrated at the beginning of the investigation when Socrates initially posed the WF question. ${ }^{47}$

Furthermore, the rejection of the final definition and so terminal aporia of the investigation also results from confusion of tò phrases. Pleasure through sight and hearing is identified with beneficial pleasure, and beneficial pleasure contains the concept of the beneficial. Accordingly, Socrates says:

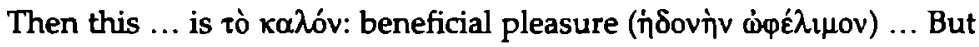

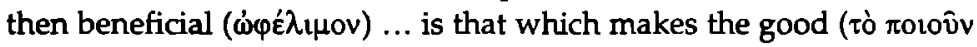

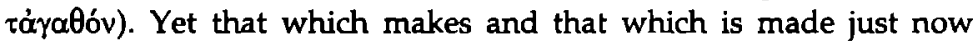

47 Compare Dancy's (2004, 177-85) treatment of the argument. Dancy remarks: '[Socrates's] use of the definite article in these lines is erratic' (178); 'Socrates is not consistent in his use of the definite article here' (182). Dancy concludes that the 'argument is an experiment that failed' and 'unsound' (185). He does not, however, understand the reason for the failure; nor does he correlate the fallacy of ambiguity on which the failure of the argument hinges and the confusion of to phrases at the beginning of the investigation. 
appeared different from one another. And so our present discussion has returned to the previous discussion. For neither could the good (to $\dot{\alpha} \gamma \alpha \theta \dot{\mathrm{o} v}$ ) be beautiful nor the beautiful (tò $k \alpha \lambda \dot{\mathrm{v}}$ ) good, if each of them is different from the other. ( $\mathrm{Hp} \mathrm{Ma} \mathrm{303e8-304a2)}$

In sum, the problem of the semantic ambiguity of the $\tau$ ò phrase riddles the investigation from beginning to end, and the final aporia of the investigation depends precisely on a failure to disambiguate the tò phrases.

Of course, it is remarkable that in the refutation of his third and fourth definitions, Socrates himself falls victim to the ambiguity of the rò phrases, for it was he who at the beginning of the investigation suggested that the questions 'What is $f$ ' and 'What is the f?' were not semantically equivalent. Yet, as we have also seen, Socrates misguidedly concedes that since Hippias has better knowledge, the questions might be equivalent. Of course, this is inconsistent with Socrates' alleged friend's belief. But to insist that Socrates' confusion of to phrases is psychologically implausible on the grounds that his alleged friend recognizes the ambiguity of $\tau$ ì phrases is to reject one instance of psychological implausibility by appeal to grounds that admit a far more egregious condition of psychological implausibility. The split personality of Socrates throughout the investigation in Hippias Major is a dramatic device not beholden to realist injunctions. What the congenial Socrates' confusion of io phrases here and at the end of the investigation emphasizes, I submit, is the danger of naively submitting to the putative wisdom of alleged authorities such as Hippias. The disagreeable Socrates (Socrates' alleged friend and housemate), who ignores conventional etiquette and spurns popular values, knows better. But the two personalities are eo ipso not integrated into one psychologically real human being.

\section{III iii 'oủ $\sigma i \alpha^{\prime}$ at $301 b 6$}

The problem of $\tau$ ò phrases throughout the investigation provides good reason not to assume that Hippias understands ' $\tau o ̀ ~ \kappa \alpha \lambda \mathrm{v}^{\prime}$ ' at $301 \mathrm{~b} 4$ to mean beauty. Rather, I suggest that he understands ' $\tau o ̀ ~ \kappa \alpha \lambda$ ó $^{\prime}$ to mean that which is beautiful, in other words, to range over beautiful entities. ${ }^{48}$ 


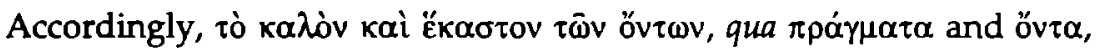
would not include beauty and the other sorts of definienda that Socrates

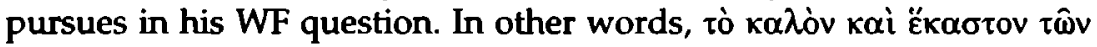
óviwv would not include $F$, but the entities that have $F$. Given this,

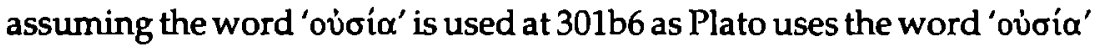
elsewhere among the early dialogues, then bodies of essence (ovioia) are not identical to the bodies of the $\pi \rho \alpha \gamma \mu \alpha \tau \alpha$ or ö $v \tau \alpha$ such as beautiful particulars. Precisely, in the case of tò $k \alpha \lambda o ́ v$, essence (ovjoía) and entity $(\pi \rho \hat{\alpha} \gamma \mu \alpha)$ correspond to beauty and that which is beautiful respectively. ${ }^{49}$

Accordingly, when Hippias criticizes Socrates and his associates for not considering the wholes of things ( $\tau \dot{\alpha}$ ó $\lambda \alpha \tau \hat{\omega} v \pi \rho \alpha \gamma \mu \alpha \dot{\alpha} \tau \omega)$ ), in the case of tò $x \alpha \lambda o ́ v$ this means that Socrates does not consider beautiful things in their entireties. Instead, Hippias accuses Socrates and his associates of

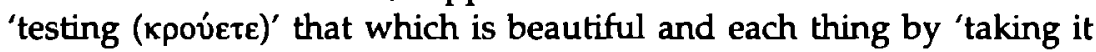
separately ( $\dot{\alpha} \pi \circ \lambda \alpha \mu \beta \alpha \dot{v} v o v \tau \varepsilon \varsigma)$ in their discussions and cutting it up

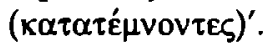

The verb ' $x p o v i \varepsilon l v '$ ', which literally means to strike, is here used figura-

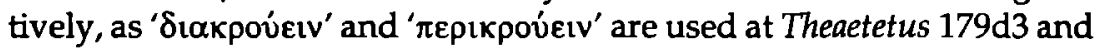
Philebus 55c7 respectively, to refer to the practice of tapping a vessel in order to determine its structural soundness. ${ }^{50}$ The participle ' $\alpha$ ' $\pi \lambda \alpha \mu$ -

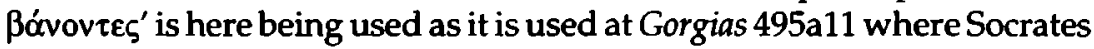
is developing the position that a person is never sick and healthy at the same time. He begins with an example of ophthalmia: 'Consider, for example, any part of the body you like, taking it by itself ( $\dot{\alpha} \pi \circ \lambda \alpha \beta \dot{\omega} v)$. A man may have a disease of the eye'. Accordingly, in Hippias Major, Hippias is claiming that Socrates takes that which is beautiful and each thing by itself and tests it. In a sense, this is an accurate and uncon-

as a quantifier phrase, which ex hypothest is not a referring expression, and Hippias'

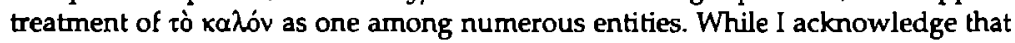
this complicates my interpretation, I do not see that it weakens it; for Hippias' use of the to phrase as a quantifier phrase does not entail his understanding of it as a non-referring expression.

49 If we are to interpret Hippias himself as a psychologically plausible character - an assumption that seems to me debatable - then, regardless of whether he is confused about tò phrases, he must at this point recognize an ontological distinction between $F$ and $f$ entities. For further consideration of this point and the problem it raises, see section $\mathrm{V}$.

50 I owe these two citations to Grube (1926), 140. 
troversial account of Socrates' pursuit of the WF question. For example, consider Socrates' question to Critias in Charmides: 'Don't you think it is a common good for more or less everyone that it should become clear

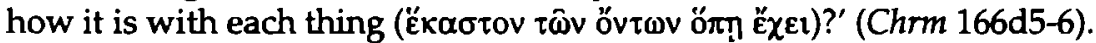
On the other hand, up to this point Hippias has understood the WF question to ask 'What is that which is $f$ ' not 'What is F?'.

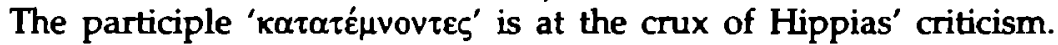
Indeed, the place of the participle at the end of the sentence is emphatic. Hippias claims that Socrates in his discussions cuts up that which is beautiful and each thing. ${ }^{51}$ In opposition to Socrates' discursive dissection, Hippias insists that bodies of essence are so great (oü $\tau \omega \mu \varepsilon \gamma \alpha \dot{\alpha} \lambda \alpha$ ) by

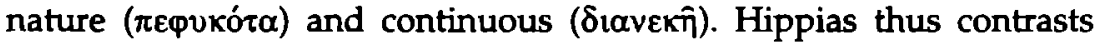
Socrates' $\lambda$ ó $\gamma o 1$ about things with the nature ( $\varphi v \sigma(\zeta)$ of things themselves: in nature bodies of essence are so great and continuous, whereas in Socrates' discussions they are dissected.

Hippias' reference to Socrates' dissection is of course figurative; Socrates dissects in discourse, not actually. Still, it is a question how figura-

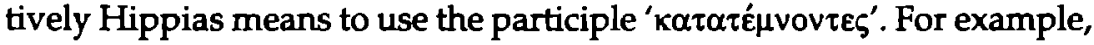
we speak of analyzing the beauty of beautiful things or of mentally distinguishing beauty as an aspect of beautiful things. But Hippias conceives of Socrates' dissection more literally; he claims that Socrates dissects, albeit in discourse, physical parts of physical things.

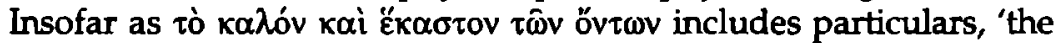
wholes of things ( $\tau \grave{\alpha}$ ö $\lambda \alpha \tau \hat{\omega} v \pi \rho \alpha \gamma \mu \alpha \dot{\alpha} \omega v$ )' refers to these particulars in

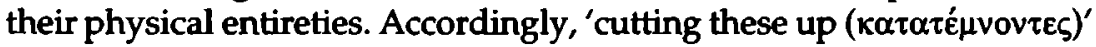
refers to distinguishing different physical parts of the particulars. What

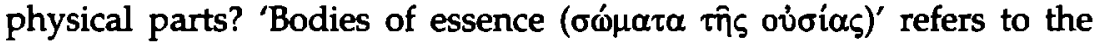
ovioíal, understood as physical bodies, of the $\pi \rho \alpha \gamma^{\prime} \mu \alpha \tau \alpha$. For example, in the case of that which is beautiful, a given beautiful thing, say, a maiden,

51 Compare Socrates' description of his method in Phaedo: 'I was afraid my soul would be blinded if I looked at things with my eyes and tried to grasp them with any of my senses. So I thought I must have recourse to accounts (hópovs) and to examine

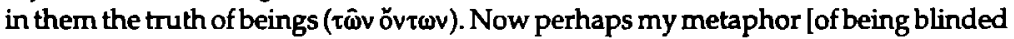
by looking at the sun during an eclipse] is not quite accurate; for I do not grant in

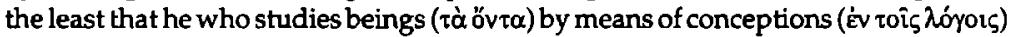
is looking at them in images any more than he who studies them in deeds (év toîs Éprous). However, that is the way I began' (Phd 99e-100a). 
is a physical whole and the ovoi $\alpha$ that makes her beautiful (= beauty), is itself a physical body.

Hippias claims that on account of their habit of discursive dissection, Socrates and his associates have overlooked the fact that bodies of being

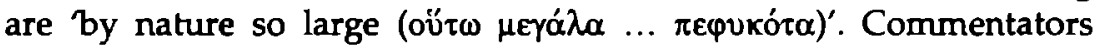
typically translate the adverb 'oü $\tau \omega^{\prime}$ as emphatic; viz., 'so large' as in very large. But with the adjective ' $\mu \epsilon \gamma \alpha{ }^{\prime} \lambda \alpha^{\prime}$ it is more natural to take the adverb 'ỡ $\omega$ ' as a correlative. As such, it implies that bodies of essence are as great as something else. The question is what else. According to my interpretation, Hippias is claiming that bodies of ovoí $\alpha_{1}$ are as great as the entities that possess them. In other words, ovoial, which make entities what they are, have the same spatial extension as the entities that possess them. ${ }^{52}$

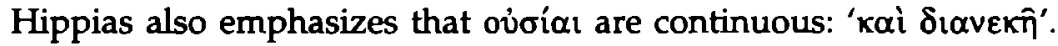
There are at least two ways to interpret this phrase. If the correlative

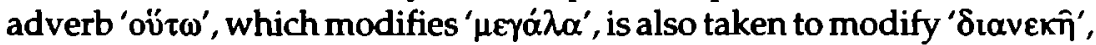
then by the continuousness of the bodies of essence Hippias would mean that each ovoí $\alpha$ is continuously extended throughout each entity that possesses it. But this interpretation is undermined by several considera-

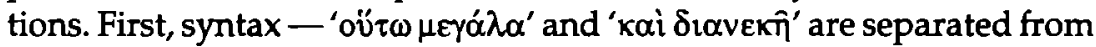

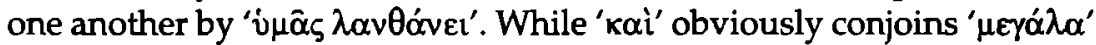

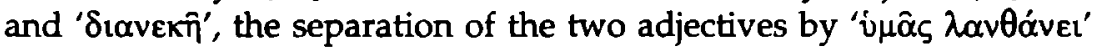
suggests that the correlative adverb 'ovi $\tau \omega$ ' may only modify ' $\mu \varepsilon \gamma \alpha$ ' $\lambda \alpha$ '.

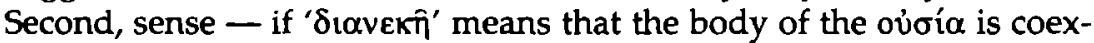
tensive with the entity that possesses it, ${ }^{53}$ then ' $\kappa \alpha i \delta$ $\delta \alpha v \varepsilon \kappa \bar{\eta}$ ' is redundant.

52 I note that while Hippias conceives of ovoial and the entities that possess them as spatial and coextensive, it is unclear precisely how to interpret their coextension. Consider two alternatives. The spatial extension of ovoial and the entities that possess them may be identical, that is, they may have the same volume. Or oviai and the entities that possess them may have the same or approximately the same surface areas. In other words, ovoíat may, as it were, coat the entities that possess them. Consider in this case Hippias' second definition gold; entities are beautified by gilding. Insofar as Hippias conceives of beauty sensually and cosmetically, the second alternative, however counterintuitive, might in fact be the one he has in mind.

53 The following objection might be raised. Although two bodies have the same extension, one may be discontinuously or non-uniformly extended. Therefore, their magnitudes may differ. I grant this, but see no evidence in the text to support the interpretation of ' $\delta$ เ $\alpha v \varepsilon \kappa \bar{n}$ ' that this objection encourages. 
Consequently, I suggest that 'oí $\tau \omega$ ' should not be taken to modify

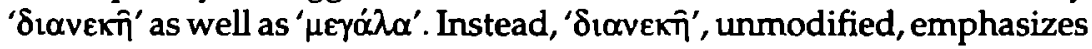
that the ovoí $\alpha$, which makes a given entity the kind of thing that it is, is continuously extended throughout the aggregate of entities of that kind. For example, given a set of beautiful particulars, the beauty (ovioía) which makes beautiful each particular in that aggregate is present in each of the particulars. ${ }^{54}$

Admittedly, (i) the continuity of ovioí $\alpha$ among the aggregate of entities of a kind follows from (ii) a physical conception of oviri and the claim that bodies of ovioi $\alpha$ are as large as the entities that possess them. But it is one thing to claim (i) and another thing to emphasize (ii). I am suggesting that the logic of Hippias' expression is that since (i), therefore (ii).

With this, we have arrived at Hippias' rejection of discontinuous properties. Given that bodies of essence are as large as the entities that possess them, it follows that these essences are continuous among aggregates of entities of a given kind. Consequently, discontinuous properties do not exist.

\section{III iv ' $\pi \alpha \theta_{0} \theta \varsigma$ ก̂ ov̉oíav' at $301 \mathrm{~b} 8$}

Hippias concludes his criticism of Socrates with the following words:

And now it has escaped you to such an extent that you think there is something ( $\tau 1)$, either an affection ( $\pi \dot{\alpha} \theta 0 \varsigma$ ) or an essence (ovoíav), which exists in the case of these things [Ps and $P h]$ conjointly, but not separately, or in the case of each, but not both.

Up to this point Hippias has been speaking of bodies of essence (ovioía) and their relation to entities that possess them. He now includes $\pi \alpha \dot{\theta} \theta$ and subsumes ov่oí $\alpha$ and $\pi \alpha \dot{\theta} \theta$ os under a more general, albeit vague category $(\tau \imath)$. This maneuver raises two questions. Why does Hippias now include the concept $\pi$ ó $\theta_{\circ}$ ? And why does he subsume ovioí $\alpha$ and $\pi \alpha \dot{\theta}$ os under a more general category?

In discussing the use of ovoi $\alpha$ in Euthyphro in particular, we noted the distinction between ovं $\sigma i \alpha$ and $\pi \dot{\alpha} \theta$ os. Furthermore, we noted that the ovi $\sigma i \alpha-\pi \alpha \theta_{0}$ os distinction includes two elements of the trinity ovoría-

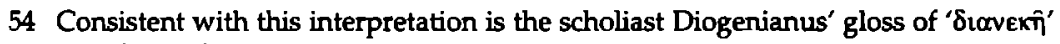

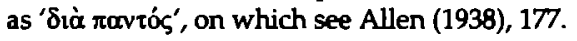




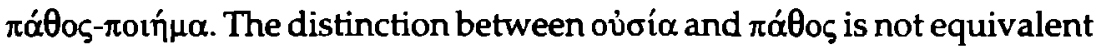
to that between essence and accident because $\pi \circ i_{n} \mu \alpha \tau \alpha$ as well as $\pi \dot{\alpha} \theta \eta$ might be accidental features of a thing. For example, Socrates running does not identify what Socrates is. Furthermore, 'property' is an unsat-

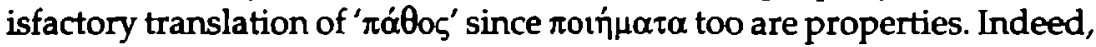
ovoial are also properties. This might encourage the view that the

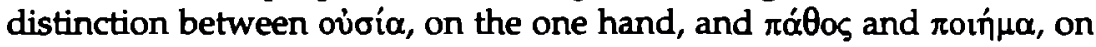
the other, is equivalent to the distinction between essence or essential properties and accidental properties. But surely Plato would not want to say that seeing is an accidental property of the eye or that being seen is an accidental property of color and shape. It is most prudent, then, to

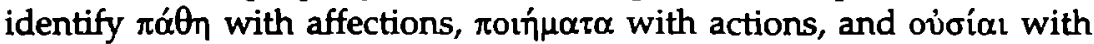
essences, and to speak of all of these as properties. It must be emphasized, however, that Plato himself has no word for property. Yet when

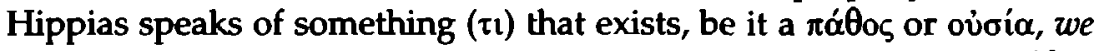
may reasonably identify the nondescript category under which $\pi$ átos and ovi $\sigma i \alpha$ fall as that of property.

It remains a question why Hippias introduces $\pi \alpha \dot{\theta} \theta \circ$ at all since his criticism is specifically of Socrates' misconception of bodies of ov̉oi $\alpha$, not bodies of $\pi \dot{\alpha} \theta \eta$. The reason is that Socrates himself introduces the concept of $\pi$ á $\theta$ os when he first considers the relation between $K$ and $P s, P h$, and

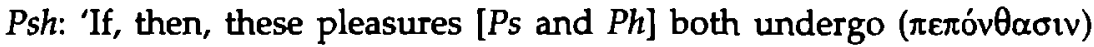
something, but each does not, they would not both be beautiful because

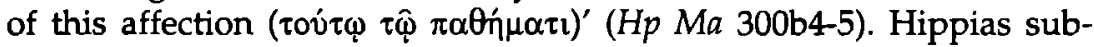
sequently follows Socrates' lead and speaks in terms of affections and being affected. Accordingly, the question in fact should not be why at $301 b 8$ Hippias introduces the word ' $\pi \alpha \dot{\theta} \theta 0 \varsigma^{\prime}$ in the disjunction ' $\pi \dot{\alpha} \theta 0 \varsigma \hat{\eta}$ ov $\sigma^{\prime} \alpha v^{\prime}$ ', but why at $301 \mathrm{~b} 6$ he speaks of bodies of essence (ovं $\sigma^{i} \alpha$ ) rather than bodies of affection ( $\pi$ á⿴囗十). The answer to this question is that Hippias, in speaking of Socrates and his associates' customary discursive dissections, alludes to the WF question and the WF question seeks an ovioí $\alpha$, for $F$ is the ovjoí $\alpha$ of beautiful things. ${ }^{55}$ Hippias subsequently includes the word ' $\pi \alpha \theta_{0} \sigma^{\prime}$ ' because in defense of his continuity principle,

55 I acknowledge that this explanation entails that Hippias here comprehends the nature of Socrates' WF question in a way that may seem inconsistent with his confusion of the WF question up to this point in the investigation. I discuss this point in section $\mathrm{V}$. 
the properties that he introduced into the discussion - being just, healthy, tired, wounded, struck 'or being affected ( $\pi \varepsilon \pi \circ v \theta \dot{\omega} \varsigma)$ in any way whatsoever, being golden, silver, ivory, of noble-birth, wise, honored, old, young, or anything else you wish that happens to humans' include $\pi \alpha \theta^{\theta}$. Thus, Hippias' continuity principle includes ov $\sigma i \alpha_{l}$ of the kind that the WF question pursues as well as $\pi \alpha \theta_{\eta}$. For this reason, at the beginning of the paper, I introduced the continuity principle as concerning the continuity of properties, rather than merely affections.

\section{III v 'ov̉oía' at 302c5}

There is one further instance of 'ov $\sigma{ }^{\prime} \alpha$ ' in Hippias Major that deserves brief consideration:

For I said at the beginning of this discussion that pleasures through sight and hearing were beautiful not because of that thing that each [Ps and $P h$ separately] happens to have experienced, but not both conjointly, but because of that thing that both conjointly and each separately have experienced; for you granted that both conjointly and each individually were beautiful. For this reason, I thought that if both conjointly were beautiful, it was because of that being ( $(\hat{\eta}$ ovooía) that attends

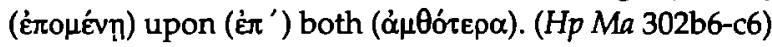

In view of the preceding interpretation of Hippias' criticism, this passage is significant in two respects. The first is that in speaking here of $K$ as an ovoía, Socrates himself clearly recognizes a distinction between ovoi $\alpha$ and the entities, $P s$ and $P h$, that possess the ov $\sigma i \alpha$. This strongly supports my interpretation of the distinction in Hippias' criticism between that which is beautiful (iò $\kappa \alpha \lambda o ́ v)$, a $\pi \rho \hat{\alpha} \gamma \mu \alpha$, and that because of which that which is beautiful is beautiful, an ovंoí $\alpha$.

Socrates' use of 'ov ${ }^{\prime} \alpha^{\prime}$ ' at 302c5 is also significant for the following reason. As we noted, Socrates initially speaks of $K$ as a $\pi \alpha \dot{\theta} \theta$; ; while in his criticism Hippias initially speaks of ovंoí $\alpha$, but subsequently extends the application of the continuity principle to include both ov $\sigma i \alpha$ and $\pi \dot{\alpha} \theta \eta$. It is a question, then, why Socrates himself switches from talk of $\pi \dot{\alpha} \theta$ os to ovंoía. Of course, we may say that Socrates simply follows Hippias' usage, but I propose a more substantive explanation. $P s$ and $P h$ are identifiable in at least two distinct ways, qua pleasures and qua beautiful things. As we noted, when Socrates first speaks of $P s$ and $P h$, he distinguishes them from other sensory pleasures, namely pleasures 
through touch, taste, and smell. The relation of $K$ to $P$ s and $P h$ qua pleasures is that of $\pi \dot{\alpha} \theta 0 \varsigma$, for pleasures are not pleasures insofar as they possess $K$. But the relation of $K$ to $P s$ and $P h$ qua beautiful things is that of ovoía, for beautiful things are beautiful because they possess $K$.

\section{The Function of Hippias' Critique}

I suggest that Plato composes Hippias' critique of Socrates at 301b2-c2 and Socrates' response in order to criticize a corporeal conception of $F$ and of the relation between $F$ and $f$ entities (hereafter referred to as the Ff relation).

In view of his first two definitions, it is clear, at least in the initial stages of the investigation, that Hippias conceives of $F$ and of the $F f$ relation corporeally. Hippias' corporeal conception of $F$ and of the $F f$ relation is complicit with his interpretation of the meaning of to phrase in the WF question as that which is beautiful; Hippias' first response to the question

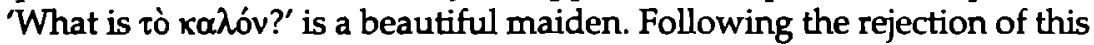
definition, Socrates encourages Hippias to reconsider the WF question: 'Do you still think that the beautiful itself (aủtò tò $\kappa \alpha \lambda$ óv), by which

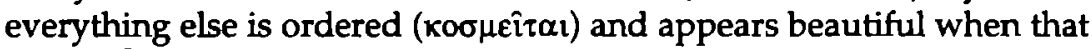
Form ( $(\hat{i} \delta \circ \varsigma)$ is added ( $\left.\pi \rho \circ \sigma \gamma^{\prime} v \eta \tau \alpha l\right)$, is a young woman, horse, or lyre?' ( $\mathrm{Hp} \mathrm{Ma} \mathrm{289d2-4).} \mathrm{Here} \mathrm{Socrates} \mathrm{describes} \mathrm{the} F f$ relation as one of

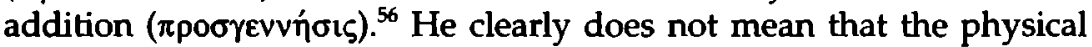
attachment of $F$ to $f$ particulars makes them beautiful. But Hippias' conception of $F$ and of the $F f$ relation appears to be quite concrete. Under the influence of the verb ' is adorned, and the word ' $\mathrm{Ei} \delta \mathrm{o} \zeta$ ', which he interprets to mean visual aspect or appearance, Hippias takes Socrates to be asking him to identify the kind of physical thing that when added to other objects, beautifies them.

56 Compare Phd 100d4-e3: '... nothing else makes it [whatever is beautiful] beautiful than the presence or communion with that thing which is the beautiful itself (avion

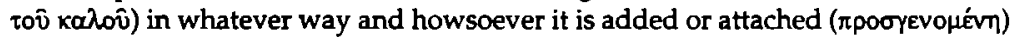
- for I do not yet confidently affirm this. But I do assert that all beautiful things become beautiful because of the beautiful ( $\tau \overline{\hat{\varphi}} \mathbf{\alpha} \alpha \lambda \hat{\omega})$. For this seems to me to be the safest reply to myself and to another ... that [it is] because of the beautiful ( $\tau \hat{\varphi}$ kod $\hat{\varphi})$ [that] beautiful things become beautiful'. 
Furthermore, given Socrates' emphasis on the purity condition - that $F$ must not admit the contrary of $F$ - Hippias considers the sort of physical thing that is not in any respect ugly and so whose capacity to beautify objects through its addition is greater than any other. His solution is gold; objects are made fine through gilding. Thus, the $\mathrm{Ff}$ relation is conceived as one of physical contiguity.

Granted that in the first stages of the investigation Hippias conceives of $F$ and of the $F f$ relation corporeally, it may well be doubted whether his conception of $F$ and of the $F f$ relation remains corporeal throughout

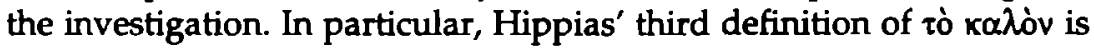
of a paradigmatic Greek male life: to be rich, healthy, honored by the Greeks, to reach old age, and after having provided a beautiful funeral for one's parents, to be beautifully and magnificently buried by one's own children. Thus, arguably by the time Hippias proposes his third definition, he no longer conceives of the definiendum as corporeal; consequently, he would not conceive of the $F f$ relation as corporeal.

Certainly when he proposes his third definition, Hippias cannot have a corporeal conception of tò katòv in mind. Nevertheless, he might revert to one later in the investigation. Among other early Platonic definitional dialogues, there are examples of interlocutors who revert to a particular conception of $F$ at some later point in the investigation following the rejection of that conception. For example, in Lysis Lysis and Menexenus initially agree that friendship is based on likeness; this conception is subsequently refuted, but at the end of the investigation, they again suppose that friendship is between likes. Another example occurs in Euthyphro. Euthyphro initially suggests that the holy is the god-beloved; this definition is refuted, but at the end of the dialogue Euthyphro re-commits himself to this view.

Plato's composition of such conditions seems to suggest that Socrates' interlocutors are deeply wedded to particular, often conventional conceptions. Consequently, one counter-argument, however sound, may not suffice to disabuse an interlocutor of a misguided view. Indeed, certain interlocutors are especially intractable. Consider Socrates' statement to Callicles late in the investigation in Gorgias: 'Callicles, the love of Demos in your soul resists me. And yet if we were to examine these same matters frequently and perhaps better, you would be convinced' (Grg 513c7-d1). Compare also Socrates' claim in Apology that the time constraints on legal proceedings undermines his ability to convince the jury, though he is confident he could succeed if he had the leisure.

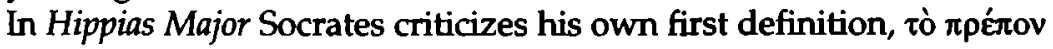
(the decorous or proper), on the grounds that the decorous makes things 
appear, not be beautiful. Hippias agrees that the decorous makes things appear beautiful. But, as his following remark indicates, he understands this claim concretely: 'as when a man takes clothes or shoes that fit, even if he is laughable [without these accoutrements], he appears to be more beautiful [with them]' ( $\mathrm{Hp} \mathrm{Ma} \mathrm{294a4-5).} \mathrm{Thus,} \mathrm{here,} \mathrm{as} \mathrm{in} \mathrm{the} \mathrm{case} \mathrm{of} \mathrm{his}$ second definition, Hippias seems to conceptualize tò $k \alpha \lambda$ óv $^{\text {in sensual }}$ and corporeal terms.

Once more, as we have seen in considering Hippias' critique of Socrates' commitment to discontinuous properties, and specifically his use of the word ' $\sigma \omega \omega_{\alpha} \alpha \alpha$ ' at 301b6, Hippias treats the ovoí $\alpha$ that makes things beautiful as corporeal.

Granted that Hippias' remarks at various points throughout the investigation suggest that he conceives of $F$ and of the $F f$ relation in corporeal terms, it is not coincidental that the evidence I have cited for Hippias' corporeal conception derives specifically from the initial stages of the first movement of the investigation, the consideration of Socrates' first definition, and the final definition. To appreciate the reason for this correlation between the evidence for Hippias' corporeal conception of $F$ and the $F f$ relation and the structure of the investigation as a whole, we need to further clarify the structure of the investigation.

As I suggested above, the investigation is divisible into three movements: Hippias' three definitions, Socrates' first three definitions, and Socrates' fourth and final definition. My reason for dividing Socrates' definitions into two movements is as follows. In the course of the proposal and examination of Hippias' first three definitions, beauty is conceptualized in three distinct modes. Hippias initially conceives of $F$ sensually, specifically in terms of visual perception. A beautiful maiden and gold are attractive to the eye. In criticizing Hippias' second definition, Socrates argues that a figwood ladle is more beautiful than a golden ladle because it is more useful. Through this criticism, beauty is conceptualized in terms of instrumentality or functionality. Finally, Hippias' third definition is ethical.

Socrates' first three definitions correspond to each of these modes of conceptualizing beauty: the decorous, which is conceived in sensual terms and rejected on the grounds that it makes things appear rather than be beautiful; the useful, which is rejected on the grounds that that which is instrumental to a bad end is not beautiful (that is, has negative value); and the beneficial, which of course entails the concept of goodness.

The fundamental difference between Hippias' three definitions and Socrates' first three definitions does not, then, lie in what I am calling 
their various modes of conceptualizing beauty, but rather in the fact that Hippias' definitions are formally incorrect, whereas Socrates' definitions are formally correct answers to the WF question. By formally incorrect, I mean that Hippias' answers are not even plausible candidates for satisfying certain conditions implicit in the WF question. Precisely, these conditions include the fact that $F$ itself is identical in the case of all $f$ entities, that $F$ is that because of which all $f$ entities are $f$, and that $F$ is not identical to $f$ entities. ${ }^{57}$ Hippias' failure to provide candidates that may plausibly satisfy these conditions results from his semantic confusion of the tò phrase ' $\tau$ 'o $\alpha \alpha \lambda \mathrm{o}^{\mathrm{v}}$ ' and from his failure to appreciate that $F$ and $f$ entities belong to distinct ontological kinds. Accordingly, in response to all three of Hippias' definitions Socrates' alleged friend complains: 'stop making answers of this kind and in this way, for they are too simple minded and easy to refute' ( $\mathrm{Hp} \mathrm{Ma} 293 \mathrm{~d} 7-8$ ). Socrates' three formally satisfactory definitions then follow. In short, the first two movements of the investigation have a parallel structure in that they progress through the same modes of conceptualizing beauty in the same order.

The question now is how Socrates' fourth and final definition relates to the preceding two movements. We have seen that the rejection of Socrates' third definition is based on an error, a semantic confusion of to phrases. As such, the rejection of Socrates' third definition is misguided. On the other hand, even if the semantic confusion did not hamstring the investigation, Socrates' third definition would be unsatisfactory insofar as it lacks explanatory power, that is, substance. Assume that in fact beauty and goodness or benefit are identical; a substantive account of these things is still wanting. In this respect, consider Thrasymachus' criticism of Socrates:

And don't tell me that it [justice] is the obligatory or the beneficial or the profitable or the gainful or the advantageous, but tell me clearly and precisely what you maintain it is, for I won't accept it if you speak that sort of nonsense. (R I, 336c6-d4)

In this light, and assuming that beauty is identifiable with goodness or benefit, Socrates' fourth definition can be understood as an attempt

57 The notion of a formally correct answer to the WF question is discussed in Wolfsdorf (2003). These particular formal, so-called category conditions of the WF question are explained on page 186. 
to provide a substantive account of beauty..$^{58}$ Here Socrates appeals to an obvious conventional conception, pleasure, precisely a form of sensual pleasure. Observe that Socrates' fourth definition differs from Hippias' first definition in that it plausibly satisfies the formal conditions of the WF question and that it differs from Socrates' first definition in that it offers a substantive account. At the same time, it resembles both of these previous definitions in that it reverts to the sensual mode of conceptualizing beauty. The sensual is bound to the corporeal. For this reason, evidence for a corporeal conception of $F$ and of the $F f$ relation emerges precisely in the initial stages of the first movement, in consideration of Socrates' first definition, and in the final movement of the investigation.

In contrast to the evidence for Hippias' corporeal conception of $F$ and of the $F f$ relation, Socrates, in his criticism of Hippias' continuity principle through appeal to mathematical examples, makes it clear that the $F f$ relation is not, generally, reducible to corporeal or sensual terms. ${ }^{59}$

58 In formulating this conception of the relation between Socrates' fourth definition and his previous three definitions, I am influenced by Tarrant (1991).

59 Granted this, it is curious that Socrates nonetheless concedes to Hippias that beauty is a continuous property. Thus, one might speculate on whether Plato himself would have endorsed Socrates' concession on this point. The answer clearly depends on what substantive conception of beauty Plato would endorse. I assume that Plato would endorse the identification of beauty and goodness. If so, then the question can be reformulated in terms of what substantive conception of goodness Plato would endorse. There is only one passage in the early dialogues where Socrates offers a substantive account of goodness. The passage occurs in the Callicles episode of Gorgias after Socrates has refuted Callicles' hedonism: '... we and all things are

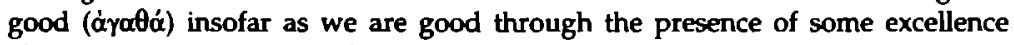

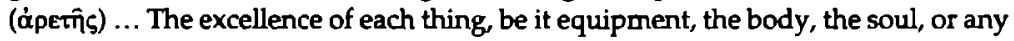

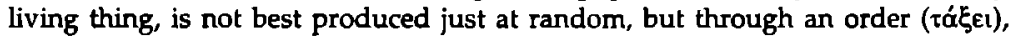

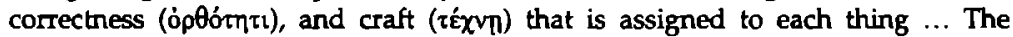

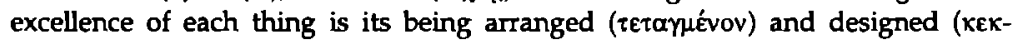

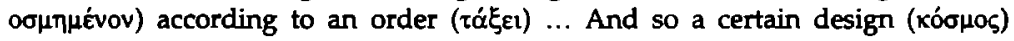
appropriate to each thing being present in each thing renders each thing good

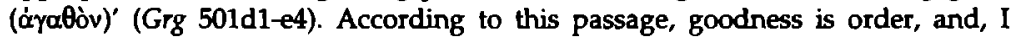
emphasize, order here replaces Callicles' conception of goodness as pleasure. Again, in Gorgias immediately following his comment that wise men call the unverse a kóoros (order), Socrates criticizes Callicles as follows: 'But it has escaped you that geometrical equality has great power among humans and gods; and you think it is necessary to exercise greed because you neglect geometry' (508b). Socrates here conceives of order in mathematical terms. This is noteworthy in relation to Socrates' examples of discontinuous properties in Hippias Major. If Plato would have en- 


\section{Conclusion}

Socrates rebuts Hippias' critique of his discursive practice and specifically of his commitment to the existence of discontinuous properties. The existence of discontinuous properties precludes a general conception of $F$ and of the $F f$ relation in corporeal terms. Nevertheless, the foregoing discussion has revealed Hippias' critique, granted its limitations, to be clearer and more complex than has previously been recognized. Hippias and Socrates' exchange is metaphysically charged. Its contents adumbrate, for instance, problems with Forms and of their relation to participants that figure in the introductory movement of Parmenides.

On the other hand, my interpretation of Hippias and Socrates' exchange is not without its problems. The main difficulty concerns the inconsistency that arguably emerges between the coherence and cogency of Hippias' critique, again, granted its limitations and the poverty of Hippias' contributions prior to this point in the investigation. In other words, for Hippias to articulate the kind of critique of Socrates that I suggest he does at 301b2-c2, arguably he would have to have a better grasp of the material under discussion than he demonstrates prior to his critique. In particular, Hippias uses 'ov $\sigma i \alpha^{\prime}$ ' consistently with Socrates' use elsewhere among the early dialogues. Yet in Hippias Major it is Hippias himself who introduces the term. Moreover, Hippias' distinc-

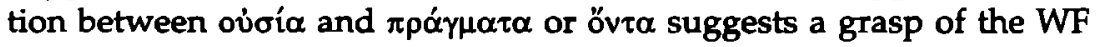
question that Hippias does not demonstrate prior to his critique. In short, my clarification of Hippias' critique arguably comes at the expense of creating some inconsistency in the portrayal of Hippias.

Assuming that this difficulty is real, I see three distinct sorts of response to it. One is to reject my interpretation of Hippias' critique for a view such as Grube's or Kahn's. That is to say, at 301b2-c2 Hippias in

dorsed the conception of goodness in Gorgias and if he would have identified beauty with order - two large ifs - then arguably he would have denied that beauty is a continuous property; for arguably order is not a continuous property. If so, this deepens the explanation of the function of Hippias' critique at 301b2-c2. Support for this speculation should include an explanation of the divergence between Plato and his character, at least the congenial half of Socrates' split personality. I defer that for another place. 
fact is confused and incoherent; he deploys sophisticated metaphysical concepts, but with an inadequate grasp of them. As I hope my discussion has shown, the textual evidence, including Socrates' response to Hippias' critique, does not support this position.

The second and third responses grant the accuracy of my interpretation. The second would seek to minimize the appearance of inconsistency between Hippias' critique and his prior contributions. More precisely, it might attempt to explain how in the course of the formulation and consideration of Socrates' fourth definition, Hippias gains a certain insight that he heretofore lacked. In support of this alternative, consider the following. Hippias' belated recognition of the ontological distinction between $F$ and entities that possess $F$ may be explained as following Socrates' distinction, in the course of his formulation of his fourth definition, between different kinds of pleasures and claim that $P s$, $P h$, and $P$ sh - unlike pleasures through touch, taste, and smell - must have $K$ in common. Consider especially Socrates' use of ' $E i \delta \delta \varsigma^{\prime}$ ' at 298b4,

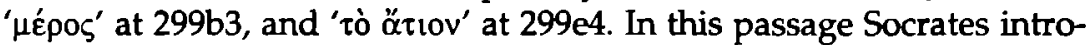
duces the concept $\mu \varepsilon \dot{\rho} \rho \varsigma$ (part) to distinguish $P s, P h$, and $P s h$ from pleasure in general. Thus, Socrates' claims may clarify for Hippias that $K$ is a part of and so distinguishable from things that possess $K$, in other words, that beauty is distinct from beautiful things.

The third alternative would simply accept that Plato's portrayal of Hippias is not entirely consistent or psychologically plausible. Instead, Plato's interest in composing Hippias' critique and Socrates' rebuttal, given the function that I have attributed to it, would be interpreted as superceding any interest that Plato might have had in complying with the strictures of realism. In support of this position, one might appeal to un-realistic dimensions of Plato's dramaturgy, perhaps especially to the bifurcation of Socrates throughout Hippias Major itself - granted that if Hippias' critique is psychologically implausible, the inconsistency is not composed as a systematic device in the way that Socrates' split personality throughout the dialogue is. Admission of some degree of unrealism in Plato's dramaturgy is, no doubt, a dangerous hermeneutic maneuver. It could be abused to bend the text to the interpreter's will, as, for instance, the appeal to Socratic irony is often conveniently used. Nonetheless, if independent evidence could be marshaled to show that there are limits to realism in the dialogues, then perhaps this third alternative would be corroborated.

The second alternative is less controversial. But at present, I need not settle the issue. So long as either the second or third succeeds, the results 
generated in the preceding pages will stand. I note the difficulty because I observe it and to suggest a direction for further inquiry.

\author{
Department of Philosophy \\ Temple University \\ 748 Anderson Hall \\ Philadelphia, PA 19122 \\ U.S.A. \\ dwolfsdo@temple.edu
}

\title{
Bibliography
}

Allen, F. et al. Scholia Platonica. American Philological Society. 1938.

Apelt, Otto. 'Die beiden Dialoge Hippias'. Neue Jahrbucher 19 (1907) 630-58; reprinted in Platonische Aufsätze. Berlin 1912. 203-37.

Bames, Jonathan. The Presocratic Philosophers. Routledge 1993.

Comford, F.M. Plato's Theory of Knowledge. Routledge 1935.

Dancy, R.M. Plato's Introduction of Forms. Cambridge University Press 2004.

Diès, Auguste. Autor de Platon. Paris 1928.

Dümmler, Ferdinand. Akademika. Giessen 1889.

Dupréel, Eugene. La légende socratique et les sources de Platon. Bruxelles 1922.

Grube, G.M.A. 'The Authenticity of the Hippias Major'. Classical Quarterly 20 (1926) 134-48. . The Logic and Language of the Hippias Major'. Classical Philology 24 (1929) 369-75.

Hom, H.J. Hippias Major Untersuchungen zur Echtheitsfrage des Dialogs. Diss. Cologne 1964.

Kahn, Charles H. 'The Genuine and the Beautiful'. Oxford Studies in Ancient Philosophy 3 (1985) 261-87.

Ludlam, Ivor. Hippias Major An Interpretation. Stuttgart 1991.

Morgan, Michael. 'The Continuity Theory of Reality in Plato's Hippias Major'. Journal of the History of Philosophy 21 (1983) 135-58.

Palmer, John A. Plato's Reception of Parmenides. Oxford University Press 1999.

Sharples, R.W. Plato's Meno. Aris \& Phillips 1985.

Soreth, Marion. Der platonische Dialog Hippias Major. Münich 1953.

Tarrant, Dorothy. The Hippias Major. Cambridge University Press 1928.

Tarrant, Harold. 'The Hippias Major and Socratic Theories of Pleasure', in Paul A. Vander Waerdt, ed., The Socratic Movement. Cornell University Press 1991, 107-26.

Thesleff, Holger. 'The Date of the Pseudo-Platonic Hippias Major'. Arctos 10 (1976) 105-17.

Vancamp, Bruno. Platon Hippias Major Hippias Minor. Stuttgart 1996. 


\section{David Wolfsdorf}

Wolfsdorf, David. 'Aikaıoúvn and 'Oolóms at Protagores 330-1'. Apeiron 35 (2002) 181-210. . 'Understanding the "What-is- $F$ ?" Question'. Apeiron 36 (2003) 175-88. . 'Euthyphro 10a2-11b1: A Study in Platonic Metaphysics since 1960'. Apeiron 38 (2005) 1-72.

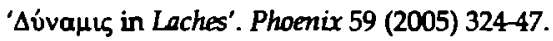

Woodruff, Paul. Plato Hippias Major. Hackett Publishing Company 1981. 